\title{
Contribution of the dopaminergic system to the effect of chronic fluoxetine in the rat forced swim test
}

\author{
Laura A. León and Fernando P. Cardenas \\ Universidad de los Andes, Bogotá, Colômbia
}

\begin{abstract}
Chronic administration of selective serotonin reuptake inhibitors (SSRI) enhances dopaminergic activity. However, the role of enhanced dopaminergic transmission in the therapeutic effects of this kind of antidepressants is still unclear. Drugs producing dopaminergic activation lead to an increment in general activity. Thus, it is reasonable to assume that some of the therapeutic effects of SSRIs are due to dopaminergic enhanced functionality. The forced swim test (FST) is a widely used test in the screening of new compounds with potential antidepressant activity. In this study the effects of pretreatment with low doses of the DA release inductor cocaine and the D2, D3 and D4 antagonist haloperidol were analyzed in the FST on rats submitted to chronic intragastric administration of the SSRI fluoxetine. Our results show that animals treated with fluoxetine and pre-treated with cocaine had significantly higher latencies than saline or haloperidol pre-treated subjects. Among both fluoxetine and saline treated animals, those pre-treated with cocaine had significant lesser immobility time. Haloperidol pre-treated animals had significantly higher immobility time than those pre-treated with saline. From these results, it is clear that the pharmacological modification of dopaminergic systems leads to behavioral changes in rats treated with both saline and fluoxetine. The FST does not have enough precision as to distinguish between dopaminergic and nondopaminergic components in the antidepressant effects of SSRIs, for this reason the use of the FST in combination to other models is mandatory. Keywords: forced swim test, antidepressant, fluoxetine, cocaine, haloperidol.
\end{abstract}

Received 19 February 2008; received in revised form 17 June 2008; accepted 17 June 2008. Available online 17 June 2008.

\section{Introduction}

The physiopathology of depression has been traditionally associated to dysfunction in noradrenergic and dopaminergic systems (Porsolt, Le Pichon, \& Jalfre, 1977; Andrews, Ninan, \& Nemeroff, 1996; Anttila \& Leinonen, 2002; Bourin, Chue, \& Guillon, 2001; Chalon et al., 2003; Delgado \& Moreno, 2000; Gupta, Nihalani, \& Masand, 2007; O'Leary et al., 2007). There is growing evidence that dopaminergic systems play an important role in both depression physiopathology and therapeutic mechanisms of some antidepressants (Ainsworth, Smith, \& Sharp, 1998; Benloucif \& Galloway, 1991; Willner, 1983; Willner, 1997; D’Aquila, Collu, Gessa, \& Serra, 2000; D’Aquila, Monleon, Borsini, Brain, \& Willner, 1997; D'Aquila et al., 2003; D'Aquila et al., 2000). The close relationship between dopaminergic dysfunction and depression arises from three main lines of evidence. The first lies in the relation between decreased dopaminergic transmission in the mesolimbic system and the genesis of behaviors such as

Laura A. León and Fernando P. Cardenas, Departamento de Psicologia, Universidad de los Andes. Please direct correspondences regarding this article to Fernando P. Cardenas, Departamento de Psicologia, Universidad de los Andes, Carrera 1 No 18A 10, Ed. Franco 2 piso, Bogotá, D.C., Colômbia. Tel.: +57 13394999 (3624); e-mail: lucarden@uniandes.edu.co. anhedonia and loss of motivation (Nestler \& Carlezon, Jr., 2006; Juckel, Sass, \& Heinz, 2003; Klimek, Schenck, Han, Stockmeier, \& Ordway, 2002; Zangen, Nakash, Overstreet, \& Yadid, 2001; Naranjo, Tremblay, \& Busto, 2001; Juckel et al., 2003).

Second, there are many clinical reports suggesting that chronic antidepressant treatment leads to an enhancement in the dopaminergic locomotor activity induced by quinpirole, D-amphetamine or apomorphine (DziedzickaWasylewska, Rogoz, Skuza, Dlaboga, \& Maj, 2002; Dziedzicka-Wasylewska, Kolasiewicz, Rogoz, Margas, \& Maj, 2000; Maj, Dziedzicka-Wasylewska, Rogoz, Rogoz, \& Skuza, 1996; Maj, Rogoz, Skuza, \& Sowinska, 1992; Maj, Rogoz, \& Skuza, 1992; Fletcher, Sinyard, Salsali, \& Baker, 2004; Callaway, Wing, \& Geyer, 1990). The increase in DA levels, found in some cerebral areas as a result of the chronic exposure to antidepressants, such as desipramine, nortriptyline and paroxetine, is an evidence of this pro-dopaminergic effect of antidepressants (Carlson, Visker, Nielsen, Keller, Jr., \& Glick, 1996; D’Aquila et al., 2003; Collu, Poggiu, Devoto, \& Serra, 1997; Collu et al., 1997; Serra, Collu, D’Aquila, \& Gessa, 1992; Serra, Collu, D'Aquila, De Montis, \& Gessa, 1990). The enhancement in locomotion induced by dopaminergic agonists (Spyraki \& Fibiger, 1981; Maj \& Wedzony, 1985) is another evidence of the pro-dopaminergic effect of antidepressants.

Third, few studies have proposed that drugs leading to the enhancement in dopaminergic transmission could act 
as potential antidepressants in both animal modeling and human clinical practice (Muscat, Towell, \& Willner, 1988; Muscat \& Willner, 1989; Muscat, Papp, \& Willner, 1992; Sampson, Willner, \& Muscat, 1991; Kinney, 1985; Basso et al., 2005). Therefore, the precise role of the dopaminergic system and of the different types of dopaminergic receptors is not fully understood. It has been demonstrated that the activation of D2 and D3 receptors could affect the forced swim test (Basso et al., 2005; Siuciak \& Fujiwara, 2004).

Since its introduction in 1977, the forced swim test (FST) is one of the most widely used animal models for depression (Porsolt et al., 1977; Basso et al., 2005; Connor, Kelliher, Harkin, Kelly, \& Leonard, 1999; GutierrezGarcia et al., 2003; Kitamura \& Nagatani, 1996; Maj \& Rogoz, 1999; Page, Detke, Dalvi, Kirby, \& Lucki, 1999; Plaznik, Danysz, \& Kostowski, 1985b; Reneric, Bouvard, $\&$ Stinus, 2002). It consists of a $40 \mathrm{~cm}$ diameter cylinder, filled with water until a height of $30 \mathrm{~cm}$ from the bottom. In this apparatus, the rat (or mouse) is allowed to swim twice with an interval of 24 hours. In the first swim session (pre-swim session) the animal is allowed to swim for 15 minutes. After this time, the animal is removed from the apparatus and gently dried. Twenty-four hours later, the subject enters the apparatus once more and is allowed to swim for only five minutes. In this swim session, rats and mice show a decrease in the swimming time. The latency of the first immobility and the total immobility time have been traditionally used as indices of "behavioral despair", similar to the characteristic behavior in human depressive states (Bourin et al., 2001; Corrigan, Denahan, Wright, Ragual, \& Evans, 2000; Fava, 2003). Drugs with antidepressant potential significantly increase latency and reduce immobility; for this reason this test is widely used in the screening of new compounds with potential antidepressant effects (Cryan, Page, \& Lucki, 2002; Hedou, Pryce, Di Iorio, Heidbreder, \& Feldon, 2001; Karolewicz, Paul, \& Antkiewicz-Michaluk, 2001; Nakazawa, Yasuda, Ueda, \& Ohsawa, 2003; Nixon, Hascoet, Bourin, \& Colombel, 1994; Page et al., 1999; Peng, Lo, Lee, Hung, \& Lin, 2007).

Given the nature of this task, it is possible that the general locomotor level might influence the final outcome leading to a misinterpretation of the results. For example, drugs with putative effects on dopaminergic systems (enhancing motility) could be considered as having antidepressant effects (Carlezon, Jr., Mague, \& Andersen, 2003; Bertaina-Anglade, La Rochelle, \& Scheller, 2006; Clemens, Cornish, Li, Hunt, \& McGregor, 2005; Dhir \& Kulkarni, 2007; Plaznik, Danysz, \& Kostowski, 1985a). From all the above, it is clear that although there are evidences of the relation between dopaminergic activity and depression, this relation is not fully understood.

The aim of the present study was to evaluate the effect of increasing or reducing dopaminergic activity on the FST in rats previously treated with fluoxetine.

\section{Method}

\section{Animals}

Thirty-seven naive Wistar male rats (290-350g) from the animal houses of the Facultad de Psicología of the Universidad Javeriana and the Facultad de Medicina Veterinaria y Zootecnia of the National University of Colombia were used. Animals were maintained under controlled temperature $\left(22 \pm 2^{\mathrm{a}} \mathrm{C}\right), 12: 12$ dark-light cycle (lights on at 07:00 h) and housed in four per cage, with free access to food and water throughout the experiment. The experiments were conducted between 9:00 and 17:00.

\section{Drugs}

Animals in the sub-chronic treatment condition received intragastric fluoxetine (Lilly - Brazil, $2.0 \mathrm{mg} /$ $\mathrm{Kg} / \mathrm{ml}$ ) dissolved in saline solution $(0.9 \%)$ during 15 consecutive days. In the pre-treatment condition, animals received intragastric cocaine chlorhydrate $(15 \mathrm{mg} / \mathrm{Kg} / \mathrm{ml})$ or haloperidol (Jenssen, $0.3 \mathrm{mg} / \mathrm{Kg} / \mathrm{ml}$ ) dissolved in saline solution $(0.9 \%)$. The cocaine chlorhydrate was kindly donated by a laboratory that prefers to remain anonymous. A liquid chromatography analysis was carried out in order to assess the purity of the cocaine chlorhydrate. According to the literature, the doses of cocaine and haloperidol used here are considered to be low with no effects expected on locomotor activity (Cunningham \& Callahan, 1991; Kleven \& Koek, 1998; Terry, Witkin, \& Katz, 1994; West \& Weiss, 1998). In order to assess locomotor effects of these cocaine or haloperidol doses, several rats were submitted to the FST after the administration of the compounds. This preliminary study showed the absence of any observable changes in locomotor activity.

\section{Apparatus}

Behavioral tests were conducted in a modified version of the traditional FST apparatus (Porsolt et al., 1977). It consisted of a dark plastic cylinder $(40 \mathrm{~cm}$ in diameter $\mathrm{x} 60 \mathrm{~cm}$ in height). In both pre-swim and swim sessions the cylinder was filled with water $\left(23^{\circ} \mathrm{C}\right)$ until a height of $30 \mathrm{~cm}$ from the bottom. The temperature of the water was constantly monitored to prevent hypothermia.

\section{Procedure}

After the arrival at the laboratory, rats were allowed at least three days to acclimate to the vivarium conditions before the beginning of the experimental procedures. Before any experimental session, all subjects were handled and habituated to the intragastric procedure. The tubing was gently carried through the mouth into the stomach, where the drug was delivered. Two researchers performed this procedure in order to avoid lesions and excessive stress. Rats were then randomly assigned to the fluoxetine or saline treatment conditions. The treatment condition consisted in two daily intragastric applications of fluoxetine or saline solution during 15 days. On day 14, rats were submitted to a 5-min pre-swim session. After that, rats were removed from the apparatus, dried in a separate cage and returned to their home cage. Twenty-four hours later, animals from each group were randomly divided into three 


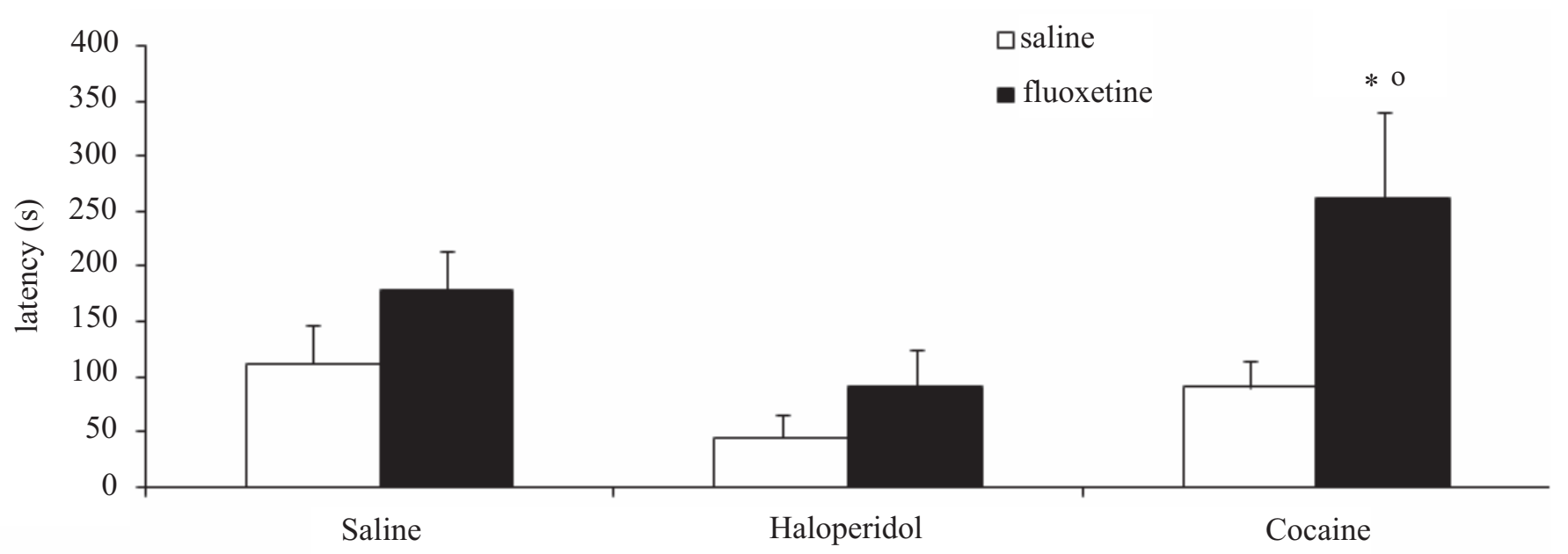

Figure 1. Immobility latencies for treatment (saline or fluoxetine) and pre-treatment (saline, haloperidol or cocaine) in the swim session. $*=$ same treatment but different pre-treatment. ${ }^{\circ}=$ same pre-treatment but different treatment $(\mathrm{p}<.05)$.

groups according to the following pre-treatment conditions: haloperidol, cocaine or saline, administered 45,5 and 10 minutes before the test, respectively. The intervals of 45 and 5 seconds were preferred according to previous data obtained in our laboratories. The interval of 10 minutes was randomly selected. After the administration of the drug, all animals were tested for the second time in the same apparatus and were allowed to swim during a period of five minutes (swim session). Accordingly, the experiment was composed of six groups of animals: Saline-Saline, Saline-Haloperidol, Saline-Cocaine, Fluoxetine-Saline, Fluoxetine-Haloperidol and Fluoxetine-Cocaine.

The total immobility time and the latency to the first episode of immobility were recorded. Immobility was defined as the absence of any movement except those necessary to float. The behavior of all subjects was recorded by a video camera connected to a computer in an adjacent room and digitized for further analysis.

The experiments were performed in compliance with the Colombian ethical recommendations for laboratory animal care (law 84-1989 and political resolution 84301993 of the Colombian Health Department).

\section{Statistical Analysis}

Immobility latency and total immobility time data were analyzed using a two-way (treatment $\mathrm{x}$ pre-treatment) analysis of variance (ANOVA). When needed, differences between group means were compared using the Student Newman-Keuls test. In all cases, data were deemed significant when $\mathrm{p}<.05$.

\section{Results}

\section{Immobility latencies}

Figure 1 shows the immobility latencies for the treatment and pre-treatment groups in the swim session. In this session, the ANOVA showed that there were no significant differences for treatment, $\mathrm{F}(1,31)=1.39$, $\mathrm{p}$
$=.25$, or pre-treatment factors, $\mathrm{F}(2,31)=1.04, \mathrm{p}=.37$. However, the interaction between both was significant, $\mathrm{F}(2$, $31)=8.75, p<.001)$. The comparison of the mean values for the groups showed that animals treated with fluoxetine and pre-treated with cocaine had significantly higher latencies than saline or haloperidol pre-treated subjects ( $p$ $<.05)$. The comparison between the mean values of the groups also showed that among subjects pre-treated with cocaine, the latencies were higher for fluoxetine than for saline treated animals $(\mathrm{p}<.05)$.

\section{Immobility time}

Figure 2 shows the percentage of immobility time for subjects treated with saline or fluoxetine in the swim session. The ANOVA showed that there were no significant differences for the treatment, $\mathrm{F}(1,31)=3.73, \mathrm{p}=.06)$ or pre-treatment conditions, $\mathrm{F}(2,31)=2.22, \mathrm{p}=.13$. However, the interaction between the two factors showed significant differences, $\mathrm{F}(2,31)=6.86, \mathrm{p}<.01$. The comparison of the mean values for the groups showed that among fluoxetine treated animals, those pre-treated with cocaine had significantly less immobility time than those pre-treated with saline $(p<.05)$. It was also found that haloperidol pretreated animals had significantly higher immobility time than those pre-treated with saline $(\mathrm{p}<.05)$. The comparison of the mean values for the groups also showed that among saline treated animals, those pre-treated with cocaine had significantly lesser immobility time than those pre-treated with saline $(p<.05)$. Finally, the comparison between the mean values of the groups also showed that among subjects pre-treated with cocaine the immobility time was higher for saline- than for fluoxetine-treated animals $(\mathrm{p}<.05)$.

\section{Discussion}

Chronic administration of fluoxetine is known to enhance dopaminergic activity (Ainsworth et al., 1998; Arnt, Hyttel, \& Overo, 1984; Zhang et al., 2000). Our 
results show that chronic fluoxetine treatment slightly enhances activity in the forced swim test as indicated by the increased latency and the slightly reduced time of immobility in the swim session. One common argument against the validity of the FST as an animal model of depression relies on the fact that control subjects (not submitted to any procedure for the induction of depression) enhance their general activity. Such an increment in activity could reflect an enhanced dopaminergic function, rather than the suggested antidepressant effect. Accordingly, our results showed that fluoxetine treated animals slightly enhanced their swimming activity. Nevertheless, it could be argued that the handling procedure required for the intragastric administration of the drug could induce stress leading to a depressive behavior. However this does not seem to be the case. In general, procedures employed to induce depression use different kinds of simultaneous mild stressors in order to prevent habituation to a repeated type of stimulus (Willner, Muscat, \& Papp, 1992). The procedure used here for intragastric application was identically performed every time, facilitating the habituation and making the situation relatively stress-free. Therefore, it can be concluded that the experimental situation did not reach the level of stress needed to induce depression. Moreover, the daily behavioral reports during the whole experiment were negative for stress for all groups.

Thus, the incremented motility could be better understood as a consequence of the enhanced dopaminergic activity. Two possible mechanisms could be proposed as responsible for this enhanced dopaminergic activity. On the one hand, fluoxetine could tonically increase the activity of dopaminergic neurons. On the other hand, fluoxetine could induce a decrement in DA release and, as a consequence, the amount of DA receptors would be upregulated with a resultant sensitizing effect. The clinical evidence of the amount of time needed by SSRI antidepressants to begin the therapeutic effect and some early reports on DA1 and DA2 mRNA enhanced expression in rats chronically treated with SSRI's (Ainsworth et al., 1998) seem to support the latter. However, recent evidence indicates that SSRI's, and in particular fluoxetine, could increase the spontaneous activity of DA neurons in the mesencephalic ventral tegmental area (Sekine, Suzuki, Ramachandran, Blackburn, \& Ashby, Jr., 2007). Here we found that chronically saline-treated rats showed a slight decrement in latency when pre-treated with cocaine. However, the same cocaine dose markedly increased the latency and decreased the immobility time in chronically fluoxetine-treated animals. Given that cocaine is not a direct agonist, but a DA releaser, this result suggests that the mechanism underlying the fluoxetine-induced motility is not merely the enhancement in the number of DA receptors (sensitization), but the increase in the number of active cells releasing DA, or both.

The reduced immobility time induced by cocaine, in addition to the fact that both saline and fluoxetine treated rats showed enhanced immobility time when pre-treated with haloperidol, clearly suggest a strong dopaminergic effect upon the swimming task. Since haloperidol acts as a D2-type antagonist (D2, D3 and D4), it could be proposed that at least these receptors are involved in mediating the dopaminergic effects in this behavioral task.

From our results, it is clear that the pharmacological modification of dopaminergic systems leads to behavioral changes in rats treated with both saline and fluoxetine. Therefore, it appears that the FST, in spite of being the preferred animal model for depression, is not sensitive enough to differentiate dopaminergic motor components from other components, i.e. serotonergic (emotional) or noradrenergic (motivational). For the sake of precision in animal modeling, we suggest that, in addition to the FST, other animal models would be important to evaluate depression-related properties of new potential antidepressant compounds, i.e. active avoidance, social isolation, learned helplessness, behavioral despair, genetic depression models or pharmacological models.

\section{Acknowledgment}

The authors are particularly grateful to Dr. J. LandeiraFernandez, for his invaluable help during all these years. The authors also wish to thank Evelyn Ruge, Camilo

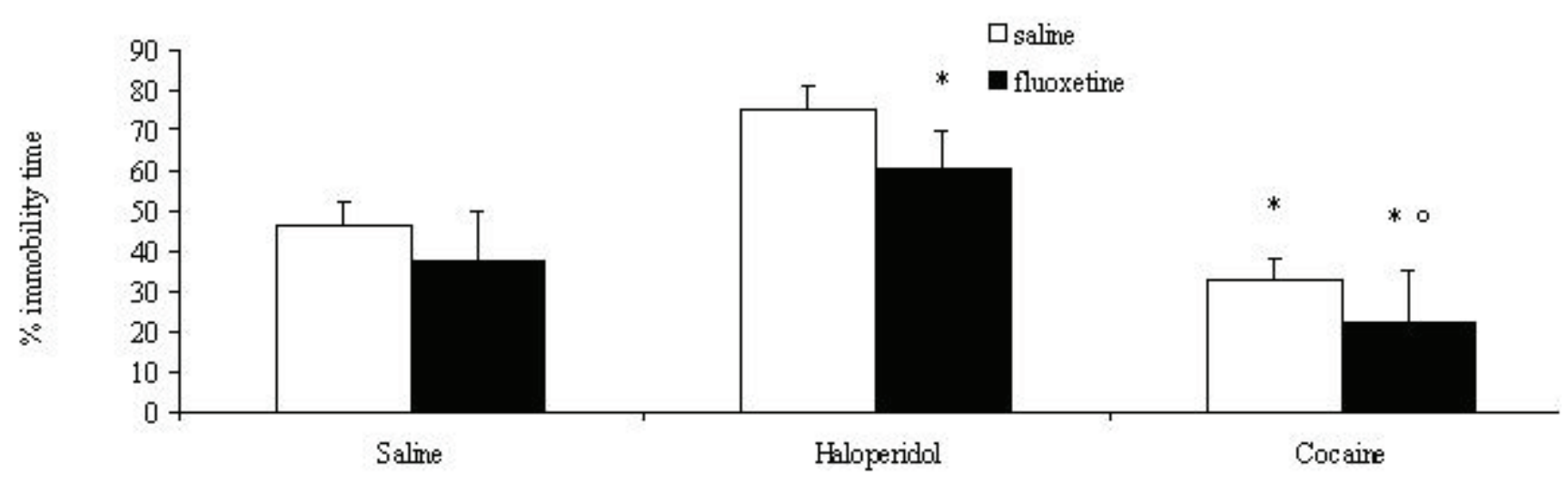

Figure 2. Percentage of immobility time for treatment (saline or fluoxetine) and pre-treatment (saline, haloperidol or cocaine) in the swim session. $*=$ same treatment but different pre-treatment. ${ }^{\circ}=$ same pre-treatment but different treatment $(\mathrm{p}<.05)$. 
Espinosa, Lucas García, Angélica Romero, and Michael Merchán for their technical assistance during part of the experimental period. This work was partly supported by the Universidad de los Andes - FAPA project.

\section{References}

Ainsworth, K., Smith, S. E., \& Sharp, T. (1998). Repeated administration of fluoxetine, desipramine and tranylcypromine increases dopamine D2-like but not D1-like receptor function in the rat. Journal of Psychopharmacology, 12, 252-257.

Andrews, J. M., Ninan, P. T., \& Nemeroff, C. B. (1996). Venlafaxine: a novel antidepressant that has a dual mechanism of action. Depression, 4, 48-56.

Anttila, S., \& Leinonen, E. (2002). Duloxetine Eli Lilly. Current Opinion in Investigational Drugs, 3, 1217-1221.

Arnt, J., Hyttel, J., \& Overo, K. F. (1984). Prolonged treatment with the specific 5-HT-uptake inhibitor citalopram: effect on dopaminergic and serotonergic functions. Polish Journal of Pharmacology and Pharmacy, 36, 221-230.

Basso, A. M., Gallagher, K. B., Bratcher, N. A., Brioni, J. D., Moreland, R. B., Hsieh, G. C. et al. (2005). Antidepressant-like effect of $\mathrm{D}(2 / 3)$ receptor-, but not $\mathrm{D}(4)$ receptor-activation in the rat forced swim test. Neuropsychopharmacology, 30, 1257-1268.

Benloucif, S., \& Galloway, M. P. (1991). Facilitation of dopamine release in vivo by serotonin agonists: studies with microdialysis. European Journal of Pharmacology, 200, 1-8.

Bertaina-Anglade, V., La Rochelle, C. D., \& Scheller, D. K. (2006). Antidepressant properties of rotigotine in experimental models of depression. European Journal of Pharmacology, 548, 106-114.

Bourin, M., Chue, P., \& Guillon, Y. (2001). Paroxetine: a review. CNS Drugs Reviews, 7, 25-47.

Callaway, C. W., Wing, L. L., \& Geyer, M. A. (1990). Serotonin release contributes to the locomotor stimulant effects of 3,4-methylenedioxymethamphetamine in rats. Journal of Pharmacology and Experimental Therapeutics, 254, 456-464.

Carlezon, W. A., Jr., Mague, S. D., \& Andersen, S. L. (2003). Enduring behavioral effects of early exposure to methylphenidate in rats. Biological Psychiatry, 54, 1330-1337.

Carlson, J. N., Visker, K. E., Nielsen, D. M., Keller, R. W., Jr., \& Glick, S. D. (1996). Chronic antidepressant drug treatment reduces turning behavior and increases dopamine levels in the medial prefrontal cortex. Brain Research, 707, 122-126.

Chalon, S. A., Granier, L. A., Vandenhende, F. R., Bieck, P. R., Bymaster, F. P., Joliat, M. J. et al. (2003). Duloxetine increases serotonin and norepinephrine availability in healthy subjects: a double-blind, controlled study. Neuropsychopharmacology, 28, 1685-1693

Clemens, K. J., Cornish, J. L., Li, K. M., Hunt, G. E., \& McGregor, I. S. (2005). MDMA ('Ecstasy') and methamphetamine combined: order of administration influences hyperthermic and long-term adverse effects in female rats. Neuropharmacology, 49, 195-207.

Collu, M., Poggiu, A. S., Devoto, P., \& Serra, G. (1997). Behavioural sensitization of mesolimbic dopamine D2 receptors in chronic fluoxetine-treated rats. European Journal of Pharmacology, 322, 123-127.

Connor, T. J., Kelliher, P., Harkin, A., Kelly, J. P., \& Leonard, B. E. (1999). Reboxetine attenuates forced swim test-induced behavioural and neurochemical alterations in the rat. European Journal of Pharmacology, 379, 125-133.

Corrigan, M. H., Denahan, A. Q., Wright, C. E., Ragual, R. J., \& Evans, D. L. (2000). Comparison of pramipexole, fluoxetine, and placebo in patients with major depression. Depression and Anxiety, 11, 58-65.

Cryan, J. F., Page, M. E., \& Lucki, I. (2002). Noradrenergic lesions differentially alter the antidepressant-like effects of reboxetine in a modified forced swim test. European Journal of Pharmacology, 436, 197-205.
Cunningham, K. A., \& Callahan, P. M. (1991). Monoamine reuptake inhibitors enhance the discriminative state induced by cocaine in the rat. Psychopharmacology (Berl), 104, 177-180.

D’Aquila, P., Monleon, S., Borsini, F., Brain, P., \& Willner, P. (1997). Anti-anhedonic actions of the novel serotonergic agent flibanserin, a potential rapidly-acting antidepressant. European Journal of Pharmacology, 340, 121-132.

D’Aquila, P. S., Collu, M., Gessa, G. L., \& Serra, G. (2000). The role of dopamine in the mechanism of action of antidepressant drugs. European Journal of Pharmacology, 405, 365-373.

D’Aquila, P. S., Peana, A. T., Panin, F., Grixoni, C., Cossu, M., \& Serra, G. (2003). Reversal of antidepressant-induced dopaminergic behavioural supersensitivity after long-term chronic imipramine withdrawal. European Journal of Pharmacology, 458, 129-134.

Delgado, P. L., \& Moreno, F. A. (2000). Role of norepinephrine in depression. The Journal of Clinical Psychiatry, 61 Suppl 1, $5-12$.

Dhir, A., \& Kulkarni, S. K. (2007). Involvement of dopamine (DA)/ serotonin (5-HT)/sigma (sigma) receptor modulation in mediating the antidepressant action of ropinirole hydrochloride, a D2/D3 dopamine receptor agonist. Brain Research Bulletin, 74, 58-65.

Dziedzicka-Wasylewska, M., Kolasiewicz, W., Rogoz, Z., Margas, W., \& Maj, J. (2000). The role of dopamine D2 receptor in the behavioral effects of imipramine--study with the use of antisense oligonucleotides. Journal of Physiology and Pharmacology, 51, 401-409.

Dziedzicka-Wasylewska, M., Rogoz, Z., Skuza, G., Dlaboga, D., \& Maj, J. (2002). Effect of repeated treatment with tianeptine and fluoxetine on central dopamine $\mathrm{D}(2) / \mathrm{D}(3)$ receptors. Behavioural Pharmacology, 13, 127-138.

Fava, M. (2003). The role of the serotonergic and noradrenergic neurotransmitter systems in the treatment of psychological and physical symptoms of depression. The Journal of Clinical Psychiatry, 64 Suppl 13, 26-29.

Fletcher, P. J., Sinyard, J., Salsali, M., \& Baker, G. B. (2004). Fluoxetine, but not sertraline or citalopram, potentiates the locomotor stimulant effect of cocaine: possible pharmacokinetic effects. Psychopharmacology (Berl), 174, 406-413.

Gupta, S., Nihalani, N., \& Masand, P. (2007). Duloxetine: review of its pharmacology, and therapeutic use in depression and other psychiatric disorders. Annals of Clinical Psychiatry, 19, 125-132.

Gutierrez-Garcia, A. G., Contreras, C. M., Diaz-Meza, J. L., BernalMorales, B., Rodriguez-Landa, J. F., \& Saavedra, M. (2003). Intraaccumbens dopaminergic lesion suppresses desipramine effects in the forced swim test but not in the neuronal activity of lateral septal nucleus. Progress in Neuropsychopharmacology and Biologial Psychiatry, 27, 809-818.

Hedou, G., Pryce, C., Di Iorio, L., Heidbreder, C. A., \& Feldon, J. (2001). An automated analysis of rat behavior in the forced swim test. Pharmacology, Biochemistry and Behavior, 70, 65-76.

Juckel, G., Sass, L., \& Heinz, A. (2003). Anhedonia, selfexperience in schizophrenia, and implications for treatment. Pharmacopsychiatry, 36 Suppl 3, S176-S180.

Karolewicz, B., Paul, I. A., \& Antkiewicz-Michaluk, L. (2001). Effect of NOS inhibitor on forced swim test and neurotransmitters turnover in the mouse brain. Polish Journal of Pharmacology, 53, 587-596.

Kinney, J. L. (1985). Nomifensine maleate: a new second-generation antidepressant. Clinical Pharmacy, 4, 625-636.

Kitamura, Y., \& Nagatani, T. (1996). Buspirone enhances immobility in the forced swim test in mice. Pharmacology, Biochemistry and Behavior, 55, 445-451.

Kleven, M. S., \& Koek, W. (1998). Discriminative stimulus properties of cocaine: enhancement by monoamine reuptake blockers. Journal of Pharmacology and Experimental Therapeutics, 284, 1015-1025.

Klimek, V., Schenck, J. E., Han, H., Stockmeier, C. A., \& Ordway, G. A. (2002). Dopaminergic abnormalities in amygdaloid nuclei in major depression: a postmortem study. Biological Psychiatry, $52,740-748$.

Maj, J., Dziedzicka-Wasylewska, M., Rogoz, R., Rogoz, Z., \& Skuza, G. (1996). Antidepressant drugs given repeatedly change the binding of the dopamine D2 receptor agonist, [3H]N-0437, 
to dopamine D2 receptors in the rat brain. European Journal of Pharmacology, 304, 49-54.

Maj, J., \& Rogoz, Z. (1999). Synergistic effect of pramipexole and sertraline in the forced swimming test. Polish Journal of Pharmacology, 51, 471-475.

Maj, J., Rogoz, Z., \& Skuza, G. (1992). The effects of combined treatment with MK-801 and antidepressant drugs in the forced swimming test in rats. Polish Journal of Pharmacology and Pharmacy, 44, 217-226.

Maj, J., Rogoz, Z., Skuza, G., \& Sowinska, H. (1992). The effect of antidepressant drugs on the locomotor hyperactivity induced by MK-801, a non-competitive NMDA receptor antagonist. Neuropharmacology, 31, 685-691.

Maj, J., \& Wedzony, K. (1985). Repeated treatment with imipramine or amitriptyline increases the locomotor response of rats to $(+)$-amphetamine given into the nucleus accumbens. The Journal of Pharmacy and Pharmacology, 37, 362-364.

Muscat, R., Papp, M., \& Willner, P. (1992). Antidepressant-like effects of dopamine agonists in an animal model of depression. Biological Psychiatry, 31, 937-946.

Muscat, R., Towell, A., \& Willner, P. (1988). Changes in dopamine autoreceptor sensitivity in an animal model of depression. Psychopharmacology (Berl), 94, 545-550.

Muscat, R., \& Willner, P. (1989). Effects of dopamine receptor antagonists on sucrose consumption and preference. Psychopharmacology (Berl), 99, 98-102.

Nakazawa, T., Yasuda, T., Ueda, J., \& Ohsawa, K. (2003). Antidepressantlike effects of apigenin and 2,4,5-trimethoxycinnamic acid from Perilla frutescens in the forced swimming test. Biological and Pharmaceutical Bulletin, 26, 474-480.

Naranjo, C. A., Tremblay, L. K., \& Busto, U. E. (2001). The role of the brain reward system in depression. Progress in Neuropsychopharmacology and Biologial Psychiatry, 25, 781823.

Nestler, E. J., \& Carlezon, W. A., Jr. (2006). The mesolimbic dopamine reward circuit in depression. Biological Psychiatry, 59, 1151-1159.

Nixon, M. K., Hascoet, M., Bourin, M., \& Colombel, M. C. (1994). Additive effects of lithium and antidepressants in the forced swimming test: further evidence for involvement of the serotoninergic system. Psychopharmacology (Berl), 115, 59-64.

O'Leary, O. F., Bechtholt, A. J., Crowley, J. J., Hill, T. E., Page, M. E., \& Lucki, I. (2007). Depletion of serotonin and catecholamines block the acute behavioral response to different classes of antidepressant drugs in the mouse tail suspension test. Psychopharmacology (Berl), 192, 357-371.

Page, M. E., Detke, M. J., Dalvi, A., Kirby, L. G., \& Lucki, I. (1999). Serotonergic mediation of the effects of fluoxetine, but not desipramine, in the rat forced swimming test. Psychopharmacology (Berl), 147, 162-167.

Peng, W. H., Lo, K. L., Lee, Y. H., Hung, T. H., \& Lin, Y. C. (2007). Berberine produces antidepressant-like effects in the forced swim test and in the tail suspension test in mice. Life Sciences, 81, 933-938.

Plaznik, A., Danysz, W., \& Kostowski, W. (1985a). A stimulatory effect of intraaccumbens injections of noradrenaline on the behavior of rats in the forced swim test. Psychopharmacology (Berl), 87, 119-123.

Plaznik, A., Danysz, W., \& Kostowski, W. (1985b). Mesolimbic noradrenaline but not dopamine is responsible for organization of rat behavior in the forced swim test and an anti-immobilizing effect of desipramine. Polish Journal of Pharmacology and Pharmacy, 37, 347-357.

Porsolt, R. D., Le Pichon, M., \& Jalfre, M. (1977). Depression: a new animal model sensitive to antidepressant treatments. Nature, 266, 730-732.

Reneric, J. P., Bouvard, M., \& Stinus, L. (2002). In the rat forced swimming test, NA-system mediated interactions may prevent the 5-HT properties of some subacute antidepressant treatments being expressed. European Neuropsychopharmacology, 12, 159171.

Sampson, D., Willner, P., \& Muscat, R. (1991). Reversal of antidepressant action by dopamine antagonists in an animal model of depression. Psychopharmacology (Berl), 104, 491-495.

Sekine, Y., Suzuki, K., Ramachandran, P. V., Blackburn, T. P., \& Ashby, C. R., Jr. (2007). Acute and repeated administration of fluoxetine, citalopram, and paroxetine significantly alters the activity of midbrain dopamine neurons in rats: an in vivo electrophysiological study. Synapse, 61, 72-77.

Serra, G., Collu, M., D’Aquila, P. S., De Montis, G. M., \& Gessa, G. L. (1990). Possible role of dopamine D1 receptor in the behavioural supersensitivity to dopamine agonists induced by chronic treatment with antidepressants. Brain Research, 527, 234-243.

Serra, G., Collu, M., D’Aquila, P. S., \& Gessa, G. L. (1992). Role of the mesolimbic dopamine system in the mechanism of action of antidepressants. Pharmacology and Toxicology, 71 Suppl 1, 72-85.

Siuciak, J. A., \& Fujiwara, R. A. (2004). The activity of pramipexole in the mouse forced swim test is mediated by D2 rather than D3 receptors. Psychopharmacology (Berl), 175, 163-169.

Spyraki, C., \& Fibiger, H. C. (1981). Behavioural evidence for supersensitivity of postsynaptic dopamine receptors in the mesolimbic system after chronic administration of desipramine. European Journal of Pharmacology, 74, 195-206.

Terry, P., Witkin, J. M., \& Katz, J. L. (1994). Pharmacological characterization of the novel discriminative stimulus effects of a low dose of cocaine. Journal of Pharmacology and Experimental Therapeutics, 270, 1041-1048.

West, C. H., \& Weiss, J. M. (1998). Effects of antidepressant drugs on rats bred for low activity in the swim test. Pharmacology, Biochemistry and Behavior, 61, 67-79.

Willner, P. (1983). Dopamine and depression: a review of recent evidence. I. Empirical studies. Brain Research, 287, 211-224.

Willner, P. (1997). The mesolimbic dopamine system as a target for rapid antidepressant action. International Clinical Psychopharmacology, 12 Suppl 3, S7-14.

Willner, P., Muscat, R., \& Papp, M. (1992). Chronic mild stressinduced anhedonia: a realistic animal model of depression. Neuroscience and Biobehavioral Reviews, 16, 525-534.

Zangen, A., Nakash, R., Overstreet, D. H., \& Yadid, G. (2001). Association between depressive behavior and absence of serotonin-dopamine interaction in the nucleus accumbens. Psychopharmacology (Berl), 155, 434-439.

Zhang, W., Perry, K. W., Wong, D. T., Potts, B. D., Bao, J., Tollefson, G. D. et al. (2000). Synergistic effects of olanzapine and other antipsychotic agents in combination with fluoxetine on norepinephrine and dopamine release in rat prefrontal cortex. Neuropsychopharmacology, 23, 250-262. 